\title{
Ewa Dębska
}

http://orcid.org/0000-0001-9986-472X

Uniwersytet Warszawski

\section{Typy podejścia do uważności młodych dorosłych w świetle wyników badań własnych}

\author{
Types of approach to mindfulness of young adults \\ in the light of the results of own research
}

Streszczenie. $\mathrm{W}$ związku $\mathrm{z}$ coraz większym zainteresowaniem uważnością (uważną obecnością) w wielu obszarach funkcjonowania człowieka autorka przedstawia wyniki badań jakościowych dotyczących rozumienia pojęcia uważności i jej praktykowania przez osoby w okresie wczesnej dorosłości. Uwzględniając aspekty teoretyczne i pragmatyczne uważności, autorka tworzy typy podejścia do uważności: Typ A - potrafi określić, czym jest uważność, i ją praktykuje, Typ B - potrafi określić, czym jest uważność, ale jej nie praktykuje, Typ C - nie potrafi określić, czym jest uważność, ale ją praktykuje, Typ D - nie potrafi określić, czym jest uważność, i jej nie praktykuje.

Słowa kluczowe: uważność, praktykowanie uważności, wczesna dorosłość

Summary. In view of the growing interest in mindfulness (attentive presence) in many areas of human functioning, the author presents the results of qualitative research on the understanding of the concept of mindfulness and its practice by people in early adulthood. Taking into account theoretical and pragmatic aspects of mindfulness, the author distinguishes four types of approach to mindfulness. Type A can describe what mindfulness is and practises it; Type B can describe what mindfulness is but does not practise it; Type $C$ - cannot describe what mindfulness is but practises it; and Type D cannot describe what mindfulness is and does not practise it. 
Keywords: mindfulness, practising mindfulness, early adulthood

\section{Wprowadzenie}

Współczesne czasy charakteryzują się światowymi głębokimi gospodarczymi kryzysami, kurczącymi się zasobami naturalnymi, przymusowym samorozwojem osobistym i zawodowym, zmierzającym do ekonomicznej produktywności człowieka (Sennett 2010). Zauważalne jest także obniżenie kondycji psychicznej u coraz większej liczby osób, przejawiające się w niskim poczuciu wartości, wypaleniu zawodowym, depresji, samobójstwach itd. Być może w odpowiedzi na tę sytuację coraz większym zainteresowaniem w wielu krajach zaczyna się cieszyć uważność (mindfulness). W związku z tym celem niniejszego opracowania jest przedstawienie wyników badań dotyczących rozumienia i praktykowania uważności przez osoby w okresie wczesnej dorosłości.

Uważna obecność określana jest przez Jona Kabat-Zinna, psychiatrę, twórcę programu redukcji stresu $\mathrm{z}$ wykorzystaniem uważności, jako swoisty stan świadomości polegający na celowym kierowaniu uwagi na to, co pojawia się aktualnie w otoczeniu zewnętrznym (wrażenia zmysłowe) i w rzeczywistości wewnętrznej (emocje, myśli, doznania fizyczne), bez osądzania treści tego doświadczenia (Kabat-Zinn 2003, 2009). W literaturze przedmiotu jest ona lokowana w różnych obszarach. Psychologowie podkreślają jej znaczenie dla profilaktyki i terapii zdrowia psychicznego (Jankowski, Holas 2009; Kabat-Zinn 2009; Radoń 2014, 2017; Segal i in. 2017). W życiu zawodowym jednostki łączona jest z celowymi zabiegami zmierzającymi do profesjonalizacji działań (Akinola 2010; Dane 2011; Hülsheger i in. 2013; Schultz i in. 2015), mówi się nawet o zarządzaniu przez uważność, zwłaszcza w kontekście kierowania zespołami pracowniczymi w organizacjach (Krishnakumar i Robinson 2015; Cacioppe 2017).

W edukacji traktowana jest ona jako proces świadomego refleksyjnego uczenia się, który wynika z wsłuchiwania się w swoje emocje, potrzeby, myśli i odczucia zmysłowe oraz reagowania na płynące z zewnątrz bodźce oraz jako zbiór ćwiczeń mentalnych ukierunkowanych na poprawę koncentracji, budowanie wspólnoty dydaktycznej, umiejętne reagowanie i dopasowanie się do sytuacji (Radoń 2014; Hassed, Chambers 2018; Wajsprych 2018; Góralska 2019). Warto jednak zauważyć, że ze względu na buddyjskie proweniencje ma ona swoich przeciwników, zwłaszcza w placówkach 
oświatowych. W każdym z tych obszarów jej praktykowanie zmierza do poprawy dobrostanu jednostki, co znajduje uzasadnienie w wynikach badań (Williams i in. 2001; Brown, Ryan 2003; Creswell i in. 2019).

\section{Założenia metodologiczne}

Przyjęte w badaniach rozumienie uważnej obecności autorstwa Kabat-Zinna uwzględnia jej konstytutywne elementy. Po pierwsze uważność ma charakter spersonalizowany, czyli jest własnością każdego człowieka, on nią kieruje i ją ćwiczy. Po drugie ma charakter intencjonalny. Oznacza to, że jednostka kieruje swoją uwagę celowo, na dany element rzeczywistości, ale też na to, czego w danym momencie doświadcza i co się z nią dzieje. Po trzecie w stanie uważności przedmiotem uwagi jest to, co jawi się świadomości w chwili obecnej. Po czwarte bez względu na emocjonalne czy poznawcze znaczenie zawarte $w$ doświadczeniu, w stanie uważności jest ono akceptowane przez jednostkę (Shapiro i in. 2006).

Celem przeprowadzonych badań jest poznanie rozumienia pojęcia uważności przez osoby w okresie wczesnej dorosłości. Postawione w badaniach problemy badawcze brzmią: W jaki sposób osoby, które biorą udział w badaniach, określają pojęcie uważności? oraz W jaki sposób osoby te odnoszą uważność do praktycznych działań? W badaniach zastosowano podejście fenomenograficzne (Męczkowska 2003), jako technikę badawczą wykorzystano wywiady ustrukturyzowane, na podstawie których dokonane zostały rekonstrukcje sposobów postrzegania świata przez 20 studentek studiów licencjackich Wydziału Pedagogicznego UW. Badania były prowadzone w Warszawie w czerwcu 2019 roku.

Opracowanie uzyskanych wyników przebiegało następująco: 1. Analizowanie poszczególnych wywiadów ze względu na określenie znajomości pojęcia uważności oraz jej cech konstytutywnych, poszukiwanie wypowiedzi, które kondensują odpowiedzi dotyczące tej samej kwestii; 2. Pogrupowanie danych według tematów, punktów widzenia poszczególnych osób na dane zjawisko; 3. Poszukiwanie różnic i podobieństw w sposobach ujęcia uważności oraz ustalenie kryteriów, na podstawie których dane odpowiedzi znalazły się w danym typie - uwzględniałam konteksty, o których mówili badani; 4. Analizowanie znaczeń w dwóch wymiarach: kolektywnym (poszukiwanie wspólnych elementów dla danej grupy badanych) oraz indywidualnym (poszukiwanie różnic między poszczególnymi jednostka- 
mi); 5. Powstanie wielowymiarowej mapy kategorii opisu. Dla prowadzonych analiz najważniejsze jest ujawnienie i stworzenie kategorii, które zostały wyłonione między innymi w wyniku połączenia, jednorodnych pod względem znaczenia, fragmentów wypowiedzi wszystkich osób biorących udział w badaniach.

\section{Analiza wyników badań}

Na podstawie analizy treści wywiadów wyodrębniłam cztery typy podejścia do uważności. Pod uwagę wzięłam dwa kryteria, pierwsze dotyczyło rozumienia terminu uważność, drugie odnosiło się do praktykowania uważności w życiu. O rozumieniu pojęcia uważności rozstrzygało uwzględnienie w jej określeniu wszystkich cech konstytutywnych.

- Typ A - potrafi określić, czym jest uważność, i ją praktykuje;

- Typ B - potrafi określić, czym jest uważność, ale jej nie praktykuje;

- Typ C - nie potrafi określić, czym jest uważność, ale ją praktykuje;

- Typ D - nie potrafi określić, czym jest uważność, i jej nie praktykuje.

Podejście typu A charakteryzuje osoby, które potrafią zdefiniować pojęcie, podać przykłady oraz praktykują uważność w życiu. Uważność określana jest jako

ukierunkowanie intencjonalne na to, co się dzieje, ale też bez oceniania tego, co się dzieje ze mną w danej sytuacji. (Edyta)

[...] myśląc o uważności, to co przychodzi mi na myśl to, że idąc na przykład ulicą, zauważamy to, co się dzieje dookoła [...] jesteśmy w stanie wychwycić, jacy ludzie są dookoła, co się dzieje wokół nas, czy jest jakaś budowa czy nie, kto trąbi. Jesteśmy po prostu w stanie skupić uwagę na otoczeniu i oprócz tego, że to dostrzegamy, to jesteśmy w stanie to jakoś zakodować w głowie, a potem odtworzyć. (Matylda)

Studentki w dużym stopniu odwołują się do swoich aktualnych stanów emocjonalnych, są skupione na doświadczaniu siebie oraz podkreślają znaczenie otoczenia zewnętrznego, obserwują świat, skupiają się na nim. 
Jak wychodzę z wydziału, to czuję powiew wiatru, czuję od razu orzeźwienie. Ja bardzo zwracam uwagę na to, co się dzieje dookoła mnie, [...] na przykład jak wczoraj pojechałam do mamy, to się źle czułam w jej mieszkaniu. I myślę sobie, co się takiego dzieje, coś tutaj jest nie tak. Okazało, że zegar przestał chodzić. (Ewelina)

Zwracam bardzo dużą uwagę na moje emocje, na to, co się dzieje w środku i potrafię je nazywać. I nawet w kontaktach ze znajomymi zawsze staram się je nazwać, żeby było mi łatwiej ich zrozumieć. Bo nie tak, że jestem zła, bo jestem zła i sobie tupnę nogą, tylko chcę lepiej opisać, co się wtedy ze mną dzieje. Jak do mnie dochodzą to je akceptuję tylko zastanawiam się jakie one są. (Halina)

Podejście typu A zatem prezentują badane, które podkreślają znaczenie własnej aktywności poznawczej, emocjonalnej i behawioralnej, a uważność towarzyszy im zarówno w sytuacjach edukacyjnych, jak i osobistych.

W narracji typu B badane osoby określają pojęcie uważności własnymi słowami:

Uważność polega na tym, że wychwytuję różne rzeczy, na przykład zapachy, dźwięki i tak dalej. (Aleksandra)

To jest tak jakby śledzenie teraźniejszości, takie bycie tu i teraz. (Agnieszka)

Badane sądzą, że uważność jest potrzebna w życiu, ale nie podejmują trudu jej praktykowania, wystarcza im świadomość znajomości zjawiska.

Mnie wystarczy, że wiem na czym polega uważność. Nie stosuję jej, nie mam takiej potrzeby. (Elżbieta)

To jest dostrzeganie tego, co nas otacza, co w danym momencie się dzieje dookoła nas i umiejętność nie tylko dostrzeżenia, ale i zanalizowania tego, zakodowania gdzieś w głowie. Jednak to wymaga nie lada pracy nad sobą. Kiedyś na pewno się tym zajmę. (Agata)

Można zatem stwierdzić, że badane świadomie rezygnują z samoobserwacji i obserwacji czynników zewnętrznych, choć nie negują jej. Być może wynika to z faktu, że studentki jako priorytetowe, w aktualnym momencie życia, traktują realizowanie zadań rozwojowych związanych z okresem wczesnej dorosłości. 
Badane, które praktykują uważność, ale nie potrafią jej nazwać, reprezentują typ C. Osoby te mają dużą praktykę w stosowaniu uważności, możliwe, że wykorzystują ćwiczenia uważności tak długo, że ta stała się ona nawykiem:

[...] ja odkąd pamiętam jak się denerwuję, to sobie liczę do dziesięciu, biorę 10 głębokich wdechów i wtedy zastanawiam się nad tym, jakie są te moje uczucia, nie chodzi tu o poradzenie sobie z tym uczuciami, ale o to, żeby wiedzieć, mieć świadomość, że one się pojawiły i przyjąć je. (Maria)

Ja w ogóle lubię się zastanawiać co się ze mną dzieje, lubię siebie obserwować, jakie myśli i emocje przychodzą mi do głowy. Po prostu są takie, jakie są. Ja je po prostu przyjmuję. (Antonina)

Uważność obecna jest w różnych sytuacjach codziennych:

[...] widzimy niebo i dla normalnego człowieka jest ono niebieskie, a dla nas ma pięć rodzajów tych błękitów. Albo wiatr jak wieje, to rozwiewa każde pasmo moich włosów i ja czuję te fale podmuchu. Zawsze zwracam uwagę na to, co się dzieje dookoła mnie i zawsze zwracam uwagę na ludzi dookoła, bo bardzo lubię ich obserwować, bo ciekawi mnie, jak wyglądają, jak się zachowują i ja bardzo lubię zwracać na takie rzeczy uwagę, ale lubię też obserwować siebie, to jak oddycham. (Julia)

Badane, choć świadomie obserwują własne wewnętrzne doznania płynące $z$ umysłu i z ciała oraz czynniki zewnętrzne, to jednak nie znają założeń leżących u teoretycznych podstaw uważności. Jej praktykowanie raczej łączą z medytacją, relaksacją, ćwiczeniami jogi.

Studentki prezentujące typ D nie rozumieją pojęcia uważności i jej nie praktykują. Podczas wywiadu wszystkie osoby starały się zdefiniować uważną obecność, niektóre $\mathrm{z}$ nich formułowały własne terminy lub odwoływały się do znanych sobie określeń znaczeniowo zbliżonych do pojęcia uważności. Te wypowiedzi zaliczono do typu D.

[...] taki sygnał płynący do naszej świadomości, tego, co się z nami dzieje, takim zastanowieniem się. Nieraz mam takie refleksje, że dlaczego ja się tak zachowałam, czemu coś takiego powiedziałam, to było zupełnie niepotrzebne. (Joanna) 
Uważność kojarzy mi się ze zdolnością do refleksji nad tym co robię. Bardzo często zdarza mi się zamyślić na przykład pojechać za daleko metrem, bo gdzieś jestem w swoim świecie, miałam wysiąść w Centrum, a wysiadam na Młocinach, bo to jest ostatnia stacja. Często mi się tak zdarza zwłaszcza wtedy, kiedy zaczynam sobie układać w głowie, co zrobię po kolei, żeby wszystko było dobrze. (Bożena)

Badane, choć starają się podać własne definicje uważności, to utożsamiają ją przede wszystkim z refleksją, środkiem niezbędnym do planowania dnia. Wszystkie wypowiedzi łączy ponadto ocenianie zachowania, co prowadzi do wniosku, że nie rozumieją pojęcia uważności w jego oryginalnym znaczeniu.

Reasumując, badane osoby uważną obecność traktują jako ćwiczenia zmierzające do własnego rozwoju, a nie jako zinternalizowany stan funkcjonowania umysłu. Nadają one zatem uważności pragmatyczny wymiar, traktują ją instrumentalnie jako praktykę wzmacniania zdolności do samoregulacji uwagi, rozwijania otwartości, ciekawości i akceptacji współczesnego świata. W odniesieniu do uwag Stanisława Radonia (2014), który zauważa dwojakie rozumienie uważności: jako cechę i jako stan, można uznać, że badane pojmują uważność nie jako cechę (czyli docelową jakość życia), charakteryzującą poszczególne osoby ze względu na czynniki środowiskowe, edukacyjne, predyspozycje genetyczne, ale jako stan umysłowej obecności przejawiający się w różnych technikach medytacyjnych.

\section{Podsumowanie}

W tekście zaprezentowano typologię postaw wobec uważności. Jest ona pierwszą, roboczą wersją przyjrzenia się uważności z perspektywy jej definiowania i stosowania. W analizach wykorzystano również tylko niektóre fragmenty przeprowadzonych wywiadów. Służy ona uporządkowaniu myślenia na jej temat i w obecnej wersji nie aspiruje do bycia podstawą do tworzenia uogólnień. Pozwala jednak na sformułowanie pewnych wskazówek dotyczących pracy z uważnością.

Osoby, które wiedzą, czym jest uważność, oraz praktykują ją w życiu osobistym, zdają się mieć w aktualnym momencie swojego życia największy potencjał do pracy $z$ innymi osobami. Z edukacyjnego punktu widzenia można zaproponować im udział w warsztatach doskonalących ich umiejętności. Z kolei badane, które praktykują uważną obecność, ale nie potrafią 
jej zdefiniować, warto zaprosić na cykl wykładów poświęconych tej problematyce. Mogą one także podczas zajęć praktycznych doskonalić swoją uważność. Osobom, które nie praktykują uważności, ale potrafią określić, czym ona jest, warto wskazać korzyści płynące $z$ jej świadomego praktykowania. Można je zachęcać do wzięcia udziału w warsztatach pracy nad sobą; pogłębiania samowiedzy dotyczącej m.in. współzależności między zjawiskami psychicznymi z somatycznymi, świadomości własnych emocji, sposobów uczenia się, świadomego reagowania na bodźce zewnętrzne, obserwowania własnych doświadczeń. Szczególną uwagę należy zwrócić na ostatnią grupę, która nie umie zdefiniować uważności i nie jest uważna. Badanym warto zaproponować udział w wykładach, warsztatach, kursach, podczas których będą mieli możliwość zapoznania się z teoretycznymi aspektami uważności oraz praktykowania jej. Uważna obecność bowiem jest kategorią, która pozwala nie tylko na bardziej efektywną współpracę $z$ innymi ludźmi, ale i na pracę nad sobą. Myślę także, że w świetle powyższych rozważań warto otworzyć dyskusję nad pytaniem: czy bycie uważnym i praktykowanie uważności są sobie tożsame?

Ponowoczesna płynność i niepewność istnienia, perturbacje gospodarcze, zdrowotne, ekonomiczne, polityczne oddziałują na jednostkę. Podmiotowe, zindywidualizowane doświadczenie własnego życia, często połączone $\mathrm{z}$ kryzysem tożsamości, $\mathrm{z}$ brakiem punktów orientacyjnych umożliwiających rozumienie siebie, a przede wszystkim z brakiem umiejętności nadania sensu swoim doświadczeniom i przeżyciom powoduje, że uważność staje się kategorią nie tylko poznawczą, ale i praktyczną. Jednak czy mimo jej medytacyjnych i kontemplacyjnych proweniencji, metodologicznych podejść, światopoglądowych zapatrywań warto ją propagować? Myślę, że cechą współczesności staje się poddawanie krytycznej refleksji własnych przekonań, a w tym praktykowania uważności.

Wydaje się, że bycie uważnym staje się konieczne w obecnych czasach. Świadoma i głęboka praca nad sobą, pojmowana w kontekście społecznym, umożliwia zachowanie dystansu do rzeczywistości, zmniejsza ryzyko zagubienia się w niej. Uważność pozwala na bycie ze sobą, w sobie, obok siebie. Jej praktykowanie prowadzi do doskonalenia kompetencji konstruowania siebie i tworzenia własnej biografii oraz głębokiego namysłu nad stosowanymi przez siebie sposobami tworzenia własnej podmiotowości, umiejętne poruszanie się między kontekstami, dokonywanie, jak to określa Paul Ricoeur (2003), przyswojenia wysiłku istnienia. Jednak uważność może stać się chwilową modą. Istnieje bowiem zagrożenie, że wzmocni ona 
kulturę indywidualizmu. Nieustanny wgląd w siebie może człowieka izolować od innych, taka osoba może dostrzegać tylko jednostkowy wymiar życia, co w konsekwencji przyczynić się może do relatywizowania i osłabiania celów wspólnotowych i publicznych.

Podsumowując, warto podejmować trud rzetelnej pracy naukowej nad zrozumieniem i praktykowaniem uważności, tak by stała się ona kategorią możliwości rozwojowych zarówno indywidualnych, jak i społecznych.

\section{Bibliografia}

Akinola M. (2010), Measuring the pulse of an organization: Integrating physiological measures into the organizational scholar's toolbox, „Research in Organizational Behavior", 30, s. 203-223.

Brown K. W., Ryan R. M. (2003), The benefits of being present: mindfulness and its role in psychological well-being, „Pers Soc Psychology”, 84(4), s. 822-848.

Cacioppe R. L. (2017), Integral mindflow: A process of mindfulness-in-flow to enhance individual and organization learning, „The Learning Organization”, 24(2), s. 408-417.

Creswell J. D., Lindsay E. K., Villalba D. K., Chin B. (2019), Mindfulness Training and Physical Health: Mechanisms and Outcomes, „Psychosomatic Medicine”, 81(3), s. 224-232.

Dane E. (2011), Paying attention to mindfulness and its effects on task performance in the workplace, „Journal of Management”, 37(4), s. 997-1018.

Góralska R. (2019), Uważność: technika uczenia się czy droga wspierania (samo)rozwoju?, „Rocznik Andragogiczny”, s. 109-124.

Hülsheger U. R., Alberts H. J., Feinholdt A., Lang J. W. (2013), Benefits of mindfulness at work: the role of mindfulness in emotion regulation, emotional exhaustion, and job satisfaction, „Journal of Applied Psychology”, 98(2), s. 310-325.

Jankowski T., Holas P. (2009), Poznawcze mechanizmy uważności i jej zastosowanie w psychoterapii, „Studia Psychologiczne”, nr 47, z. 4, s. 59-79.

Kabat-Zinn J. (2009), Życie, piękna katastrofa. Mądrością ciała i umysłu możesz pokonać stres, choroby i ból, przekł. D. Ćwiklak, Wydawnictwo Czarna Owca, Instytut Psychoimmunologii, Warszawa.

Kabat-Zinn J. (2003), Mindfulness-based stress reduction (MBSR), „Constructivism in the Human Sciences", 8(2), s. 73-107.

Krishnakumar S., Robinson M. D. (2015), Maintaining an even keel: An affect-mediated model of mindfulness and hostile work behawior, „Emotion”, 15(5), s. 579-589 .

Męczkowska A. (2003), Fenomenografia jako podejście badawcze w obszarze studiów edukacyjnych, „Kwartalnik Pedagogiczny”, nr 3, s. 71-89. 
Radoń S. (2014), Uważność, czyli medytacja w edukacji: fakty i mity, [w:] J. Zimny (red.), Współczesne zagrożenia: fakty i mity, Wyd. KUL, Lublin, s. 299-317.

Radoń S. (2017), Specyfika, funkcje i mechanizmy stanów medytacyjnych na podstawie badań neuropsychologicznych, „Annales Universitatis Mariae Curie-Skłodowska, sectio J - Paedagogia-Psychologia”, s. 111-122.

Ricoeur P. (2003), O sobie samym jako innym, przekł. B. Chełstowski, PWN, Warszawa.

Schultz P. P., Ryan R. M., Niemiec C. P., Legate N., Williams G. C. (2015), Mindfulness, work climate, and psychological need satisfaction in employee well-being, „Mindfulness”, 6(5), s. 971-985.

Segal Z. V., Williams J. M. G., Teasdale J. D. (2009), Terapia poznawcza depresji oparta na uważności. Nowa koncepcja profilaktyki nawrotów, przekł. R. Andruszko, Wydawnictwo Uniwersytetu Jagiellońskiego, Kraków.

Sennett R. (2010), Kultura nowego kapitalizmu, przekł. G. Brzozowski, K. Osłowski, Wydawnictwo Literackie Muza, Warszawa.

Shapiro S. L., Carlson L. E., Austin J. A., Freedman B. (2006), Mechanisms of Mindfulness, „Journal of Clinical Psychology”, vol. 62(3), s. 373-386.

Williams K. A., Kolar M. M., Reger B. E., Pearson J. C. (2001), Evaluation of a Wellness-Based Mindfulness Stress Reduction intervention: a controlled trial, „American Journal of Health Promotion", 15(6), s. 422-432. 